\title{
Corporate govenance and CSR - present and perspectives in Romanian economy
}

\author{
Luminita Cecilia Crenicean \\ Faculty of Tourism and Commercial Management, \\ Dimitrie Cantemir Christian University \\ Email: lumi.cecilia@gmail.com \\ Manoela Popescu \\ Faculty of Tourism and Commercial Management, \\ Dimitrie Cantemir Christian University \\ Email: manoela.popescu@gmail.com
}

\begin{abstract}
In the current economic context it can definitely be stated that the importance of corporate governance is the major key in assuming social responsibility by Romanian business organizations, leading to achieve high performance. Moreover, corporate governance refers to the distribution of rights and responsibilities between the different categories of persons involved in the company. In other words, it refers to promoting fairness, transparency and accountability at the company level, good governance of a company can be regarded as a requirement of capital market requirements and at the same time as an economic and social necessity in Romania.
\end{abstract}

Keywords: corporate governance, social responsibility, CSR

JEL Classification:

\section{Introduction}

Corporate governance has become a concept used in the development of agent theory, based on the potential conflict exists between the business owner and management. That is why, at first glance, is at least irrelevant to consider corporate governance as a basis for taking CSR by companies in the global economic context. Managers are responsible for substantiating CSR-oriented strategies. CSR (Corporate Social Responsibility) is a concept related to the contribution that companies must have in the development of a modern society. And corporate social responsibility merely align organizations interests with those of society as a whole (groups of interested partners, community etc.).

In the context of sustainable development and the global economic crisis, the performance of companies is no longer just about profit, but to do well socially. In Romanian companies, the firm objective is redefined, no longer purely economic, aimed at individual profit but social, aimed at the public good. The company does not just make profits, produce goods and services, provide jobs, pay taxes to the state, possibly to invest in research, but also to social well. Moreover, in the current economic context, potential investors are more interested in the future prospects of business development generated by the synergies of human, material, financial, cultural, informational and organizational resources. 
This means that overall performance is becoming a necessity in the current context in which the stakeholders' theory is relevant. Business management is that by identifying and reconciling the interests of all stakeholders can lead to business performance. Experts agree that the harmonization of those interests is ensured through the system of corporate governance.

Practice has shown that, over time, taking into account the business organizations of their social responsibilities will lead to economic performance and growth, as well as better conditions for future profitable business. Business organizations who assume a greater social responsibility will be more effective just by discouraging unions and government actions, for example. Over time, consideration will emphasize social responsibilities interests of shareholders and market partners.

So from the perspective of the manager, social responsibilities are undertaken primarily in order to achieve economic interests of business organizations. The motivation and cooperation with employees, market partners (suppliers, customers, union, government, etc.), local community, disadvantaged etc. are achieved high levels of profit and so the manager will assume these social responsibilities. Moreover, most managers pursuing sustainable development programs to attract new customers and remain loyal to those already existing.

It can be argued that CSR is a concept broader than corporate governance. In fact, considering that social responsibility can be approached from two perspectives: market and management, this idea is even more striking. Known is that, in management, are three areas of responsibility, arranged like concentric circles: in the center - property and shareholders; then the other groups involved and directly interested, and in the larger sphere - society. Thus, it can be defined major areas of business ethics: Corporate governance (GC); oriented management to concerned groups; corporate social responsibility (CSR). Mentioning that the last two depend on the first, the optional management strategies, based on a legislative framework that defines the fundamental principles of corporate governance, organizational practices developed by assimilating these principles.

\section{Romanian companies and their state of in interest in corporate governance and CSR}

Obviously, reality shows us that many of the Romanian businesses were profitable and assume social responsibilities from the first day of operation, without knowing that they do so, with a direct impact on business development. Thus, many companies are concerned, since their foundation, on the pursuit of professional development programs for employees (training programs and lifelong learning), and the Occupational Health and Safety programs.

An analysis of companies which have been reported CSR case studies, highlighted by CSR Romania, shows that CSR is a worthwhile investment in the long term, on organizational and societal level. Although at this point can not know the true extent of the phenomenon, there is information about multinationals that came with the expertise of CSR from outside and have adapted their models Romanian specific, but also Romanian companies that are engaged in various actions, activities and CSR programs. What is not known yet, are information regarding CSR strategies developed and implemented by local companies. It is true that there are many companies that use CSR activities to improve company image among customers and partners. 
Introducing CSR in organization, leadership, motivation, control and business evaluation is not an aim in itself but an effective way of business development. Social responsibility by any company is its social commitment which should benefit all those concerned, including company.

In Romania, companies choose the social projects according to their activity field, but not after a real dialogue with stakeholders nor analysis of the importance of their concerns and expectations. The study shows that the banking industry firms are engaged mainly in CSR projects in culture, education and financial inclusion, working for diversity and equal opportunities. Companies in the area of audiovisual projects are concerned with e-Inclusion, digital security, health, etc., and the heavy industry in environmental protection programs, safety and health at work, involvement in local communities etc.

Currently, it can be said that the successful business model is one where value creation in business also means creating value for society, in which corporate governance decides on the model of CSR development. The study shows that companies focuses on action beyond business development for the sake of development, The same survey reveals that effective CSR model in any business is the one that is provided by partnerships and alliances between NGOs, the public sector and businesses.

Moreover, CSR activities should be developed continuously and consistently in accordance with the principles of sustainability and obviously as part of the business strategy of the company. Companies that have implemented CSR as active responsibility will not give up moral and social commitment, regardless of the context. Moreover, the companies surveyed said they have reassessed CSR programs and sought to integrate them into their overall strategy. These companies are those which capitalize on during economic crisis, development opportunities through CSR.

An analysis of the most relevant companies publicized CSR supports the view that despite the economic crisis, such companies does not change CSR budgets, on the contrary, the amounts allocated to CSR programs recorded significant increases. Thus, for example, Rompetrol and Petrom allocated amounts in the millions of CSR programs. Rompetrol Group has assigned to group level about \$ 1 million, the amount necessary for the implementation of the ongoing projects as currently one - "The Energy Comes from the Soul". Petrom investment in CSR, starting in 2010 until today, was 3 million euros, needed for CSR projects in education, environment and health. By attracting European funds, the company invested 5 million euros in a project advisory of 25,000 unemployed. Obviously, these companies do not want to change their business strategies based on assuming responsibilities for all those concerned, but if they would like this would be impossible, because CSR is heavily integrated into their strategic management.

The study showed that in times of crisis, companies that manage certain actions of CSR at PR or marketing and have even been tempted to quit such activities. These companies do not assume social responsibilities towards all those concerned, but aimed at obtaining benefits related to image, increase sales, retain customers in a short time. Moreover, these companies cannot be successful on long term if does not address CSR as social commitment. 
Undertaken research on companies in Romania show that submitted studies of CSR are mostly in the fields of education, culture, environment, social, human rights, sports and in the category of those who annually report CSR are Siveco, Arctic, Vodafone, Petrom, Orange, Tuborg etc. Moreover, they enjoy a very good image and confidence among stakeholders.

Explore ways of making CSR of companies that have taken such actions, programs and projects integrated into their overall strategy reveals that innovation in CSR process is as important as any socio-human field. A search for new ways of empowerment of the company to employees, environment, community, partners, society etc. and addressing in different ways actions, activities, programs and projects in CSR CSR is key to success and hence in business.

The economic crisis has revealed that in CSR as in business, companies must develop a proactive behavior, meaning to create context and parameters needed to effective social responsibility and business development. Company relations with all its stakeholders should be guided by the teleological human factor, which is crucial in CSR issues.

In the economic crisis the concept of social enterprise came along, businesses turning to social entrepreneurship. In Romania CSR programs are focused on environmental protection and less on education, entrepreneurship and financial inclusion and economic, sport, human rights, social inclusion etc. There are only few major companies which programs in this field are developed at international level and also applied in Romania.

Referring to reported CSR, in our country the lack of transparency regarding the amounts allocated to CSR programs contribute to the failure in reporting. In other countries, CSR reporting is a duty, while in our public report of CSR is shown less consideration of firms to all those concerned, they are not reporting at all, or they are not reporting according to universal standards (Global Reporting Initiative Framework - GRI). It is conceivable that a company's CSR activities are beneficial on two levels: society and the company. As a "good citizens", companies must be "involved" in community problems, be sensitive to social needs.

Although not always linear, most studies have shown a clear relationship between CSR activities and performance of companies measured by some indicators: the benefits to shareholders, profits and marketing impact. For any organization assuming basic social responsibilities it is essential for it and ensures the survival and gives real opportunities for development.

\section{Conclusions}

The results show that CSR is that way in which businesses could contribute to the sustainable development of Romanian society, having a positive impact on companies' competitiveness. The research conducted focused on the effects it has on human resource CSR, reputation and innovation. These areas are considered important in determining the competitiveness of a company, to which interrelated. The analysis showed that the reputation that a company builds through CSR is required for retaining the workforce quality and responsible practices lead to increasing the company's reputation among customers, employees and all stakeholders, while retaining and empowering employees. Obviously, competitive and performance employees 35 
ensures that, at least, a company's competitive advantage. At romanian level, has shown that only foreign companies applied their CSR and social responsibility politics in a appropriate manner, which could be an viable example for local companies.

Involvement in social responsibility of different companies contribute directly to their development by grabbing new markets, winning new customers, increasing the prestige and positive image among all stakeholders. Also, socially responsible companies are most sought after by professionals (personal competence and performance) and by the community to develop profitable partnerships. Business networks and clusters are generated by socially responsible companies rather than other entities. The investments made by companies to assume social responsibility produced effects at both material and psychological level.

Applying efficient models of corporate governance, managers assume social responsibilities in order to achieve high performance by motivating valuable employees, by protecting the environment and community in which the company operates. Social responsibility is meant to be a new form of self-control and control over the activities carried out by commercial firms, other than the market, government regulations, trade unions and various interest groups pressures.

Although between social responsibility and financial performance of the companies may not be a direct relationship, at least in the short term, it is noted that there are many companies with significant results both financial and social responsibility. This is because they see more profit a means to the organizational efforts than an end in itself. These business organizations recognize that flexibility, change and immediate reaction to changes in the environment are vital to their survival in the context of the knowledge economy. Consequently they supervise environmental changes and constantly sustain strategies and policies they develop.

\section{References}

1. C. Crisan, (2013), Corporate and society. CSR between voluntary and duty, Tritonic Publishing House, ISBN: 9786068536828

2. L.C. Crenicean, (2013), Corporate Governance - In Romania, in the knowledge based economy context, from theory to practice, Bibliotheca Publishing House, Tîrgoviște, ISBN 978-973-712-809-6, 290pgs

3. M. Popescu, L.C. Crenicean, (2013), Business competitiveness from social responsibility perspective, in the context of knowledge-based economy, International Journal of Academic Research in Business and Social Sciences, Volume 3, Issue 4

4. Investigated studies of CSR at: http://www.responsabilitatesociala.ro/

5. Petrom Social Responsibility, viewed at: http://www.responsabilitatesociala.ro/companii/petrom.html

6. Rompetrol Social Responsibility, viewed at: http://www.rompetrol.ro/csr/impreuna-pentru-fiecare 